\title{
The acculturation and repatriation problems and school behavioral problems reported from teachers among repatriated refugee adolescents in Bosnia-Herzegovina
}

\author{
Mevludin Hasanović ${ }^{1,2}$, Izet Pajević ${ }^{1,2}$, and Slobodan Pavlovic ${ }^{3}$ \\ ${ }^{1}$ Department of Psychiatry, University Clinical Center Tuzla, Bosnia-Herzegovina \\ ${ }^{2}$ School of Medicine University of Tuzla, Tuzla, Bosnia-Herzegovina \\ ${ }^{3}$ Private agency 'EQ\&EQ' for improving the health life conditions, Tuzla, Bosnia-Herzegovin
}

\begin{abstract}
Objectives: To describe the acculturation and repatriation problems and school behavior problems reported from teachers who were amidst Bosnia-Herzegovina (BH) repatriated school adolescents who were refugees after the 1992-1995 war, and to analyze possible differences between primary and secondary school students.

Methods: The sample of 100 adolescents aged of $15.2 \pm 2.4$ years consisted from two groups: elementary and secondary school students ( $\mathrm{n}=50$, both equalized by gender), who survived the 1992-1995 war catastrophes, and were forced to spend certain refugee period in foreign country during and after this war. They were prevented to return to their original home places after repatriation because of no safety there. We used General questionnaire for personal information and trauma experiences, Personal questionnaire for acculturation and repatriation, and teacher's version of the Children Behavior Check list, for (Achenbach CBCL).

Results: Younger students reported lower adjustment and tendency to internalization. Older adolescents reported more intensive externalizing and other problems. Older adolescents reported significantly more often "thinking about his/her native place on arrival at the place of exile" and "thoughts about cousins", while younger students reported more often "couldn't play outside". Teachers reported a number of behavioral disorders that returnees showed high maladjustment during repatriation. Returnees with greater acculturation problems showed increased functional and relational problems, however, with less psycho-emotional problems after repatriation.

Conclusion: Younger students showed tendency to internalization and older adolescents showed significantly more intensive externalizing problems and other problems. Teachers have noticed a number of behavioral disorders that returnees showed as higher maladjustment during repatriation. Acculturation problems abroad were associated with functional and relational problems after returned at home.
\end{abstract}

\section{Introduction}

The use of violence and aggression against civilians during war time has become one of the most prominent military developments of this century, resulting in increasing numbers of refugees and displaced persons amidst regional and tribal conflicts [1]. Many refugees exiled to different European countries, where they have faced different types of acculturation processes [2]. 'Loss of place', acute and chronic trauma, family disruption and family reunification problems have all become issues of great concern [3].

By the beginning of the war in Bosnia and Herzegovina, in the year of 1992, new demographical movements are being formed, that are being interchanged during the war events in intensity and important characteristics. The number of forcefully displaced and expelled only from the area of former Yugoslavia, before the conflict on Kosovo, is estimated to around 3 million [4]. Although, the period of peace was established by The Dayton Agreement, in December 1995, the migrations of Bosnian and Herzegovinian population are continuing today, from Bosnia and Herzegovina and other European countries into some third country. Parallel with that, the significant number of refugee persons is coming back to their homeland Bosnia and Herzegovina, after many years of life in foreign cultures [5].

The impact of modern warfare on children is an issue that little is known of. Together with adults, many children witnessed and have been exposed to almost all, and some to all, of the experiences related to war $[2,6]$. The majority had experienced family separation, bereavement, and were in close contact with war, combat and extreme deprivation [6]. Traumatic experience has overall far reaching consequences on personality. In particular, it has significant impact on teenagers that are just approaching the phase of solving their identity problems $[7,8]$. The group that had the most difficult time with postwar adjustment, was the one comprised of young adults who, during war time, were children, ages five to 12 years old. Their condition was the result of growing up in an environment that had lacked a sense of safety and security (e.g., they could not play outdoors, and were often confined to living in interior rooms) [9].

The entire social web was destroyed, leaving the situation without a natural social support system in place. Traumatic events experienced

Correspondence to: Mevludin Hasanović, Department of Psychiatry, University Clinical Center Tuzla, Bosnia-Herzegovina, Tel: +387 35267 111; E-mail: hameaz@bih.net.ba

Key words: Bosnia-Herzegovina, adolescents, acculturation, repatriation, school behavior

Received: February 28, 2017; Accepted: March 24, 2017; Published: March 27, 2017 
by thousands of people during this conflict may very well have a lasting effect on the mental health of the country [5,7].

In 1995, after the war in Bosnia had reached its conclusion, a certain number of refugee families was repatriated. They were commonly repatriated against their wishes, not wanting to return to an environment that was completely changed by destruction and devastation, leaving it unsafe. During this process, the children were exposed to another type of stress. The stress of displacement and also the process of acculturation $[2,10]$.

The decision whether to return to their homes is a complex one, with local and international political pressure adding up to their insecurities. In addition, there is the impact of war, the experiences of violence, the remembering and issues of reconciliation, and a variety of psychosocial programs, mostly unevaluated, aimed at helping with these issues. All this has a solid impact on their health and their wellbeing, and has led to long-term emotional scars and mental health problems with children and adolescents [2,5,11]. Exposure to war violence and social isolation are highly predictive symptoms of PTSD; depressive symptomatology was accounted for, primarily by the exilerelated stressors [12]. Failure to resolve moderate to severe traumatic reactions may result in long-lasting consequences on adolescent ability to engage in productive behavior and function socially, academically, professionally, and personally adequate $[5,13]$.

Certain war experiences are also associated with ample symptomatology [14]. For adolescents who lost their fathers, the combining of dangerous environments during war and their own personal experiences on the outside of their homeland could leave them exposed to a large number of traumatic stressors that could subsequently lead to severe PTSD and many different behavioral dysfunctions $[2,5,7,8,10]$. PTSD and behavioral dysfunctions in general could affect an adolescents' ability of achieving their life goals in the future, because of an overwhelming loss of perceived power and selfesteem [15]. Displaced persons no longer felt that they were able to play a useful role; they had lost their sense of worth. Widespread depression, feelings of fatigue and listlessness may have prevented adolescents from taking steps to improve their situation. Many of the internally displaced people had a high startle capacity, and were constantly nervous. Some of the most adverse psychosocial responses increased with age and this poses serious problems $[5,10]$. The major challenges, with regards to repatriation and deconstruction are pointed out. The importance of family reunification and the facilitation of decision-making by affected people themselves, were highlighted [16].

In this study, our objectives were to describe the acculturation and repatriation problems and school behavior problems reported from teachers among Bosnia and Herzegovina $(\mathrm{B} \& \mathrm{H})$ repatriated refugee school adolescents after the 1992-1995 war, and to analyze possible differences between primary and secondary school students.

All of them survived very difficult humanitarian catastrophes being without normal life properties together with war dangerousness that they were exposed to, together with their families. During our research, they were in the process of repatriation to home country after a certain period of life in exile (1995-1998), without the possibility to return to their places of origin, despite the Daytona Peace Agreement signed in December 1995 and war definitely quitted.

\section{Methods}

\section{Study design and participants}

Data collection was held in classrooms of schools where the adolescents studied, with written permission from the Tuzla Canton Ministry for Culture, Sport and Education. The study was approved by the Human Research Ethics Board of the Tuzla University Clinical Center. During the collection of data, only the first author was alongside the examinees, with no school authorities present.

The target groups were elementary and secondary school students of early and middle adolescence, who had the status of refugees during and after the $\mathrm{BH}$ war. Participants were picked out from the available refugee students in one public elementary school and seven secondary schools, who consented to participation voluntarily; with their parents who gave verbal permission, after they had been informed and asked for participation in this research. We tested 60 elementary school students ( 30 girls) but only the questionnaires were valid for 50 (25 girls) $(83.3 \%)$ subjects. The secondary school students were sampled separately, and matched by gender and sample size, giving the total number of individuals enrolled into the study.

These repatriated adolescents were without ability to return into their original homes, from where they had been displaced/exiled. Inclusion criteria were: a) participants had to be originally from $\mathrm{BH}$ with different history of the recent war, b) adolescents had to experience war conditions in the beginning of the $\mathrm{BH}$ war, when they were forced into leaving their homes under life threatening conditions, c) adolescents were denied return to their homes, from where they forced to leave because of life threatening reasons, and still could not return. The average age of respondents was (mean \pm standard deviation) $15.2 \pm 2.4$ years: younger (elementary school students) $13.1 \pm 1.3$ years and older (secondary school students) $17.2 \pm 1.1$ years.

\section{Data collection tools}

The questionnaire, on basic personal and socio-demographic information, was designed specifically for this study. It included questions about the basic data (age, gender, education level of parents, employment status of parents, self-evaluation of the psychosocial family status, habits). Using the instructions for systematic description of cultural influence from DSM-IV, the acculturation and repatriation characteristics were determined [17]. The acculturation check list we built from 11 questions covering the following information: sadness after arriving to foreign environment(s); thought about original home in place where person exiled; trouble sleeping; digestive problems; different diet; ability to play games outside; acceptance of new environment(s); missing of friends from homeland; thought about cousins in homeland; listening to news from homeland; desire to go back home. The repatriation check list we built from 14 questions covering the following information: meeting with old friend(s) upon returning home; meeting with new friends upon return; attending the same school that he/she attended before the exile; attending the school with own generation; difficulties in mastering the school material; hardships with teachers; different schooling system than in foreign country; trouble(s) in communicating with cousins; sadness after return; capacity to concentrate to lessons; watching satellite TV on foreign country language; sleeping problems; alimentary problems; economic situation in family after return. All items are coded using "Yes" or "No" answers. The Child Behavior Checklist of Achenbach, CBCL-TRF, was used to collect data about school behavior disturbances, 
Hasanović M (2017) The acculturation and repatriation problems and school behavioral problems reported from teachers among repatriated refugee adolescents in Bosnia-Herzegovina

based on teachers' classroom observations [18]. The checklist consisted of 121 close-ended questions, that were thematically divided into these following sections: 1) anxious/depressed - 13 items, 2) withdrawn/ depressed - 8 items, 3) somatic complains - 11 items, 4) social problems -11 items, 5) thought problems -5 items, 6) attention problems -10 items, 7) rule-breaking behavior - 17 items, 8) aggressive behavior - 18 items and 9) other problems - 17 items: bowel movements (BM) out of toilet, brags, cruel to animals, doesn't eat well, bites nails, overeating, overweight, other physical problems, shows off, sleeps more, talks too much, thumb sucking, wets self (day), wets the bed, whining, wishes to be opposite sex, and other problems. Based on the CBCLTRF cutoff T-score 69.5 while respecting the symptom sections criteria, the observed prevalence rate of clinical range of behavioral problems among participants, noted by teachers in schools, was computed [18].

\section{Data analysis}

The Statistical Package for Social Sciences, version 10.0 (SPSS, Chicago, IL, USA) was used to statistically analyze the collected data. The statistical tests included the t-test, chi-square $\left(\chi^{2}\right)$ test, Fisher exact two-tailed test. The $\mathrm{P}<0.050$ was considered to be statistically significant.

\section{Results}

The socio-demographic data and exposure to trauma experience(s)

The most frequent trauma experiences regarding sociodemographic data that adolescents reported in this study were: "Insufficient funds", "Loss of family member(s)", "Inadequate settlement(s)", "Life in collective settlement(s)", "Inadequate and insecure neighborhood" and "Separation from both parents". There was no significant differences between the two groups, except that older students reported significantly more often "Separation from both parents" than younger. More than one tenth of adolescents survived loss of father, with no difference between groups. (Table 1).

Table 1. The socio-demographic data and certain trauma experiences for 100 adolescents from Bosnia and Herzegovina who are in the process of repatriation.

\begin{tabular}{|c|c|c|c|c|c|}
\hline \multirow{2}{*}{$\begin{array}{c}\text { Socio-demographical data } \\
\text { and exposure to trauma } \\
\text { experience(s) }\end{array}$} & $\begin{array}{c}|c| \\
\text { Younger } \\
(\mathrm{n}=50)\end{array}$ & $\begin{array}{c}\text { Older } \\
(\mathrm{n}=50)\end{array}$ & $\begin{array}{c}\text { Total } \\
(\mathrm{n}=100)\end{array}$ & $\chi^{2}$ & $P$ \\
\hline Inadequate settlement(s) & $21(42.0)$ & $24(48.0)$ & $45(45.0)$ & 0.364 & 0.546 \\
\hline Life in collective settlement(s) & $17(34.0)$ & $26(52.0)$ & $43(43.0)$ & 3.305 & 0.069 \\
\hline $\begin{array}{c}\text { Inadequate and insecure } \\
\text { neighborhood }\end{array}$ & $18(36.0)$ & $20(40.0)$ & $38(38.0)$ & 0.170 & 0.680 \\
\hline Separation from both parents & $9(18.0)$ & $26(52.0)$ & $35(35.0)$ & 12.723 & $<0.001$ \\
\hline Insufficient funds & $29(58.0)$ & $24(48.0)$ & $53(53.0)$ & 1.004 & 0.316 \\
\hline Loss of father & $6(12.0)$ & $7(14.0)$ & $13(13.0)$ & 0.088 & 0.766 \\
\hline Loss of a close family member & $26(52.0)$ & $23(46.0)$ & $49(49.0)$ & 0.360 & 0.548 \\
\hline
\end{tabular}

\section{Acculturation and repatriation problems}

After arriving in foreign countries, most adolescents reported thinking about their cousins and about the places of their origin. Older students reported significantly more often thinking about their original places, while younger respondents significantly more frequently expressed that they couldn't play games outside. About two thirds missed their friends from homeland, a half of them wanted to go back home, almost half of them didn't accept new environment(s), listened to news from homeland, were sad after arriving to the foreign environment(s) and had different $\operatorname{diet}(\mathrm{s})$. Almost one third had sleeping problems and one tenth had problems with Alimentary (Table 2).

The most frequent repatriation problems that adolescents reported after returning to homeland were: "Met new friends upon
Table 2. The frequency of acculturation problems between younger $(n=50)$ and older $(n=$ 50) repatriated refugees in Bosnia and Herzegovina.

\begin{tabular}{|c|c|c|c|c|}
\hline \multirow{2}{*}{$\begin{array}{c}\text { Acculturation problems during } \\
\text { the period of exile }\end{array}$} & \multicolumn{2}{|c|}{ No. (\%) adolescents who answered } & $\begin{array}{c}\text { Fisher's } \\
\text { Exact Test }\end{array}$ \\
\cline { 2 - 5 } & $\begin{array}{c}\text { Younger } \\
(\mathrm{n}=50)\end{array}$ & $\begin{array}{c}\text { Older } \\
(\mathrm{n}=50)\end{array}$ & $\begin{array}{c}\text { Total } \\
(\mathrm{n}=100)\end{array}$ & P (2-sided) \\
\hline $\begin{array}{c}\text { Were sad after arriving to foreign } \\
\text { environment(s) }\end{array}$ & $23(46.0)$ & $21(42.0)$ & $43(43.0)$ & 0.840 \\
\hline $\begin{array}{c}\text { Thought about your original home } \\
\text { in place where you exiled }\end{array}$ & $40(80.0)$ & $24(48.0)$ & $64(64.0)$ & 0.002 \\
\hline Had trouble sleeping & $15(30.0)$ & $14(28.0)$ & $29(29.0)$ & 1.000 \\
\hline Had digestive problems & $5(10.0)$ & $4(8.0)$ & $9(9.0)$ & 1.000 \\
\hline Different diet & $23(46.0)$ & $18(36.0)$ & $41(41.0)$ & 0.418 \\
\hline Couldn't play games outside & $13(26.0)$ & $23(46.0)$ & $36(36.0)$ & 0.040 \\
\hline Didn’t accept new environment(s) & $24(48.0)$ & $24(48.0)$ & $48(48.0)$ & 1.000 \\
\hline Missed friends from homeland & $33(66.0)$ & $29(58.0)$ & $62(62.0)$ & 0.537 \\
\hline Thought about cousins & $46(92.0)$ & $38(76.0)$ & $84(84.0)$ & 0.054 \\
\hline Listened to news from homeland & $25(50.0)$ & $20(40.0)$ & $45(45.0)$ & 0.422 \\
\hline Wanted to go back home & $28(56.0)$ & $22(44.0)$ & $50(50.0)$ & 0.317 \\
\hline
\end{tabular}

return", "School system was different than in foreign country", "Mostly watched satellite TV programs on foreign country language", "Economic situation in family was worse than before exile". About half of them didn't met old friend(s) after retuned to homeland and did not attend the same school as before exile. About one third of them had difficulties in mastering school material in mother language school, didn't attend school with own generation, and had sleeping problems. About one fifth reported lack of concentration to school lessons. About $4-5 \%$ of students reported difficulties in communication with cousins and teachers after returned, respectively. Only two younger students reported Alimentary problems. In terms of frequency of repatriation problems among young and elderly subjects were no statistically significant differences, except for "Doesn't attend the same school that he/she attended had before the exile" where older students reported significantly more frequent this repatriation problem (Table 3).

\section{Behavioral problems in school after return reported from teachers}

The most frequent school behavior problem that students showed in clinical and border-line manifestation reported from their teachers were "other problems", that considers: bowel movements outside the toilet, brags, animal cruelty, doesn't eat well, nail biting, overeating (gluttony), overweight (obese), other physical problems, shows off, sleeps more, talks too much, thumb sucking, wets self (day), wets the bed, whining, wishing to be of the opposite sex, and other problems. About one tenth of students had anxious-depressive and withdrawaldepressive problems and somatic difficulties. Only few students had social and thought problems. In terms of the frequency of behavioral problems in school that observed teachers of examined students there were no statistically significant differences in the clinical and/or border-line manifestation of the listed problems, except for border-line forms of internalizing problems, where younger students reported a significantly higher frequency than high school students (Table 4).

Older adolescents showed significantly higher scores on the T-scale for: thought problems, breaking rules, aggressive behavior, externalizing problems, other problems and total problems (Table 5).

\section{Association of acculturation and repatriation problems with school behavior problems}

Sadness in the exile, having different diet and sleeping troubles, listening to news from homeland and desires to return back to homeland 
Hasanović M (2017) The acculturation and repatriation problems and school behavioral problems reported from teachers among repatriated refugee adolescents in Bosnia-Herzegovina

Table 3. Frequency of repatriation problems between younger $(n=50)$ and older $(n=50)$ of returnees in Bosnia and Herzegovina

\begin{tabular}{|c|c|c|c|c|}
\hline \multirow{2}{*}{ Repatriation problems in period when returning home } & \multicolumn{3}{|c|}{ No. (\%) adolescenata who answered "Yes" } & \multirow{2}{*}{$\begin{array}{c}\text { Fisher's Exact Test } \\
P(2-\text { sided }\end{array}$} \\
\hline & Younger $(\mathrm{n}=50)$ & Older $(\mathrm{n}=50)$ & Total $(n=100)$ & \\
\hline Didn't meet old friend(s) upon returning home & $21(42.0)$ & $28(56.0)$ & $49(49.0)$ & 0.261 \\
\hline Met new friends upon return & $45(90.0)$ & $44(88.0)$ & $89(89.0)$ & 1.000 \\
\hline Doesn't attend the same school that he/she attended had before the exile & $19(38.0)$ & $30(60.0)$ & $49(49.0)$ & 0.045 \\
\hline Doesn't attend school with own generation & $17(34.0)$ & $11(22.0)$ & $28(56.0)$ & 0.265 \\
\hline Has difficulties in mastering the school material & $22(44.0)$ & $15(30.0)$ & $37(74.0)$ & 0.214 \\
\hline Has hardships with teachers & $4(8.0)$ & $1(2.0)$ & $5(5.0)$ & 0.362 \\
\hline System of schooling is different than in foreign country & $41(82.0)$ & $47(94.0)$ & $88(88.0)$ & 0.121 \\
\hline Has trouble in communicating with cousins & $2(4.0)$ & $2(4.0)$ & $4(4.0)$ & 1.000 \\
\hline Was sad after return & $30(60.0)$ & $21(42.0)$ & $51(51.0)$ & 0.109 \\
\hline Can't concentrate to lessons & $10(20.0)$ & $9(18.0)$ & $19(19.0)$ & 1.000 \\
\hline Mostly watches satellite TV on foreign country language & $37(74.0)$ & $38(76.0)$ & $75(75.0)$ & 1.000 \\
\hline Had sleeping problems & $11(22.0)$ & $17(34.0)$ & $28(28.0)$ & 0.265 \\
\hline Had Alimentary problems & $2(4.0)$ & 0 & $2(2.0)$ & 0.265 \\
\hline Economic situation in family is worse than before exile & $38(76.0)$ & $41(82.0)$ & $79(79.0)$ & 0.624 \\
\hline
\end{tabular}

Table 4. Frequency of school behavioral problems according Achenbach CBCLTRF (clinical and/or border-line manifestation) among younger $(\mathrm{n}=50)$ and older returnees $(\mathrm{n}=50)$ in Bosnia and Herzegovina by ratings of their teachers.

\begin{tabular}{|c|c|c|c|c|c|c|c|}
\hline \multirow{2}{*}{$\begin{array}{c}\text { Behavioral problems } \\
\text { (Achenbach - CBCLTRF) }\end{array}$} & \multirow{2}{*}{ Form } & \multicolumn{3}{|c|}{ No. (\%) adolescenata } & \multirow[b]{2}{*}{$\chi^{2}$} & \multirow[b]{2}{*}{ df } & \multirow[b]{2}{*}{$P$} \\
\hline & & Younger $(\mathrm{n}=50)$ & Older $(\mathrm{n}=50)$ & Total $(n=100)$ & & & \\
\hline \multirow{2}{*}{ Anxious-depressive } & Border line & $7(14.0)$ & $1(2.0)$ & $8(8.0)$ & 4.909 & 2 & 0.086 \\
\hline & Clinical & $2(4.0)$ & $2(4.0)$ & $4(4.0)$ & & & \\
\hline \multirow{2}{*}{ Withdrawal-depressive } & Border line & $3(6.0)$ & $6(12.0)$ & $9(9.0)$ & 5.011 & 2 & 0.082 \\
\hline & Clinical & $4(8.0)$ & 0 & $4(4.0)$ & & & \\
\hline \multirow{2}{*}{ Somatic difficulties } & Border line & $2(4.0)$ & $4(8.0)$ & $6(6.0)$ & 1.099 & 2 & 0.577 \\
\hline & Clinical & $1(2.0)$ & $2(4.0)$ & $3(3.0)$ & & & \\
\hline \multirow{2}{*}{ Internalizing problems } & Border line & $8(16.0)$ & 0 & $8(8.0)$ & 8.696 & 2 & 0.003 \\
\hline & Clinical & 0 & 0 & 0 & & & \\
\hline \multirow{2}{*}{ Social problems } & Border line & $2(4.0)$ & 0 & $2(2.0)$ & 2.041 & 2 & 0.153 \\
\hline & Clinical & 0 & 0 & 0 & & & \\
\hline \multirow{2}{*}{ Thought problems } & Border line & $1(2.0)$ & $2(4.0)$ & $3(3.0)$ & 0.344 & 2 & 0.558 \\
\hline & Clinical & 0 & 0 & 0 & & & \\
\hline \multirow{2}{*}{ Other problems $\dagger$} & Border line & $3(6.0)$ & $7(14.0)$ & $10(10.0)$ & 4.637 & 2 & 0.098 \\
\hline & Clinical & $27(54.0)$ & $32(64.0)$ & $59(59.0)$ & & & \\
\hline
\end{tabular}

$\dagger$ bowel movements out of toilet, brags, cruel to animals, doesn't eat well, bites nails, overeating, overweight, other physical problems, shows off, sleeps more, talks too much, thumb sucking, wets self (day), wets the bed, whining, wishes to be opposite sex, and other problems.

Table 5. The difference in the severity of the school behavior problems of school adolescents according the Achenbach CBCLTRF (T-scores) between younger $(\mathrm{n}=50)$ and older $(\mathrm{n}=50)$ of returnees in Bosnia and Herzegovina.

\begin{tabular}{|c|c|c|c|c|}
\hline $\begin{array}{c}\text { Achenbach CBCLTRF } \\
(\text { T-scores })\end{array}$ & $\begin{array}{c}\text { Younger } \\
(\mathrm{n}=50)\end{array}$ & Older $(\mathrm{n}=50)$ & t-test & $P$ \\
\cline { 2 - 5 } & Mean \pm Standard deviation & & \\
\hline Anxious-depressive & $53.5 \pm 7.8$ & $54.1 \pm 5.6$ & 0.457 & 0.648 \\
\hline Withdrawal-depressive & $53.9 \pm 6.8$ & $53.6 \pm 5.4$ & 0.196 & 0.845 \\
\hline Somatic difficulties & $52.1 \pm 5.5$ & $53.6 \pm 6.2$ & 1.285 & 0.202 \\
\hline Internalizing problems & $53.2 \pm 6.2$ & $53.8 \pm 4.8$ & 0.566 & 0.573 \\
\hline Social problems & $52.2 \pm 5.6$ & $54.4 \pm 6.3$ & 1.859 & 0.066 \\
\hline Thought problems & $49.8 \pm 3.1$ & $51.5 \pm 4.5$ & 2.101 & 0.038 \\
\hline Problems in concentration & $51.0 \pm 2.4$ & $52.1 \pm 3.2$ & 1.834 & 0.070 \\
\hline Breaking of rules & $50.7 \pm 3.5$ & $55.4 \pm 6.0$ & 4.756 & $<0.001$ \\
\hline Aggressive behavior & $50.0 \pm 3.1$ & $53.3 \pm 5.7$ & 3.591 & 0.001 \\
\hline Externalizing problems & $50.4 \pm 3.1$ & $54.3 \pm 5.5$ & 4.426 & $<0.001$ \\
\hline Other problems $\dagger$ & $63.3 \pm 11.5$ & $67.7 \pm 10.5$ & 2.023 & 0.046 \\
\hline Total problems & $52.5 \pm 4.0$ & $54.9 \pm 4.2$ & $2 ., 808$ & 0.006 \\
\hline
\end{tabular}

were positively associated with anxious-depressive, withdrawaldepressive problems, with somatic difficulties, internalizing problems and thought problems. Thinking about ones' home after the arrival to the place of exile positively associated with anxious-depressive and withdrawal-depressive problems, somatic difficulties, and internalizing problems; but it inversely correlated with attention problems, breaking of rules, aggressiveness and with the total problems.

Alimentary problems in exile positively associated with anxiousdepressive and withdrawal-depressive problems as well as with internalizing problems also it positively correlated and with breaking rules.

The lack of possibility to play games outside apartment in the place of exile directly correlated with the thought problems but negatively associated with: attention problems, breaking of rules, aggressiveness, externalizing, other problems and total problems. The successful acceptance of a new surrounding in exile, inversely correlated with: somatic difficulties, thought problems, other problems and total problems. The lack of old friends negatively associated with social problems, problems of attention, aggressiveness, externalization and other problems. The thinking about cousins in exile negatively associated with social problems, problems of attention, breaking the rules, aggressiveness, externalization, other and total problems (Table 6).

Watching satellite TV program mostly on foreign language of the country of exile, sadness after returning and problems with sleeping after returning were negatively associated with most acculturation problems during the stay in exile while the annoyance in studying of school material in direct correlation with most of acculturation problems during exile (Table 7). 
Hasanović M (2017) The acculturation and repatriation problems and school behavioral problems reported from teachers among repatriated refugee adolescents in Bosnia-Herzegovina

Table 6. Pearson " $\mathrm{r}$ " correlation coefficient of behavioral problems (Achenbach) and acculturation problems among returnees in Bosnia and Herzegovina ( $\mathrm{n}=100$ ).

\begin{tabular}{|c|c|c|c|c|c|c|c|c|c|c|c|c|c|}
\hline $\begin{array}{l}\text { Behavioral problems } \\
\text { (Achenbach) } \dagger \rightarrow \\
\text { Acculturation } \\
\text { problems } \downarrow\end{array}$ & & $\begin{array}{l}\text { Anxious- } \\
\text { depressive }\end{array}$ & $\begin{array}{l}\text { Withdrawal- } \\
\text { depressive }\end{array}$ & $\begin{array}{c}\text { Somatic } \\
\text { difficulties }\end{array}$ & $\begin{array}{c}\text { Internalizing } \\
\text { problems }\end{array}$ & $\begin{array}{c}\text { Social } \\
\text { problems }\end{array}$ & $\begin{array}{l}\text { Thought } \\
\text { problems }\end{array}$ & $\begin{array}{l}\text { Attention } \\
\text { problems }\end{array}$ & $\begin{array}{c}\text { Breaking of } \\
\text { rules }\end{array}$ & Aggressiveness & $\begin{array}{c}\text { Externalizing } \\
\text { problems }\end{array}$ & $\begin{array}{c}\text { Other } \\
\text { problems }\end{array}$ & $\begin{array}{c}\text { Total } \\
\text { problems }\end{array}$ \\
\hline Sad in exile & $\mathrm{r}$ & $0.289^{* *}$ & $0.320 * *$ & $0.297 * *$ & $0.341 * *$ & -0.057 & $0.219^{*}$ & -0.117 & 0.046 & -0.147 & -0.047 & -0.095 & 0.112 \\
\hline $\begin{array}{l}\text { Thought about home } \\
\text { place }\end{array}$ & $\mathrm{r}$ & $0.274 * *$ & $0.307^{* *}$ & $0.236^{*}$ & $0.308^{* *}$ & -0.181 & 0.136 & $-0.298 * *$ & $-0.231 *$ & $-0.338 * *$ & $-0.294 * *$ & -0.119 & -0.033 \\
\hline $\begin{array}{l}\text { Had sleeping } \\
\text { troubles }\end{array}$ & $\mathrm{r}$ & $0.313^{* *}$ & $0.426 * *$ & $0.337 * *$ & $0.404 * *$ & 0.026 & 0.131 & -0.064 & 0.185 & -0.108 & 0.049 & 0.019 & $0.207^{*}$ \\
\hline $\begin{array}{l}\text { Had digestion } \\
\text { troubles }\end{array}$ & $\mathrm{r}$ & $0.378^{* *}$ & $0.583 * *$ & 0.162 & $0.426^{* *}$ & 0.021 & 0.019 & 0.061 & $0.249^{*}$ & -0.078 & 0.099 & 0.115 & $0.255^{*}$ \\
\hline Different diet & $\mathrm{r}$ & $0.514 * *$ & $0.467 * *$ & $0.466^{* *}$ & $0.547 * *$ & 0.088 & $0.393 * *$ & -0.078 & 0.141 & -0.073 & 0.042 & 0.078 & $0.306^{* *}$ \\
\hline $\begin{array}{c}\text { Couldn't play games } \\
\text { outside }\end{array}$ & $\mathrm{r}$ & 0.069 & -0.046 & 0.157 & 0.067 & -0.185 & $0.205^{*}$ & $-0.284 * *$ & $-0.412 * *$ & $-0.329 * *$ & $-0.391 * *$ & $-0.291 * *$ & $-0.206^{*}$ \\
\hline $\begin{array}{c}\text { Accepted new } \\
\text { environment }\end{array}$ & $\mathrm{r}$ & -0.188 & -0.001 & $-0.291 * *$ & -0.180 & -0.153 & $-0.334 * *$ & -0.098 & -0.045 & -0.106 & -0.077 & $-0.339 * *$ & $-0.231 *$ \\
\hline Missed old friends & $\mathrm{r}$ & 0.156 & 0.146 & 0.159 & 0.173 & $-0.266^{* *}$ & 0.173 & $-0.279^{* *}$ & -0.178 & $-0.337 * *$ & $-0.265^{* *}$ & $-0.434 * *$ & -0.155 \\
\hline $\begin{array}{l}\text { Thought about } \\
\text { cousins }\end{array}$ & $\mathrm{r}$ & 0.028 & 0.058 & -0.050 & 0.015 & $-0.584 * *$ & 0.087 & $-0.622 * *$ & $-0.601 * *$ & $-0.770 * *$ & $-0.713 * *$ & $-0.451^{* *}$ & $-0.463 * *$ \\
\hline $\begin{array}{l}\text { Listened to news } \\
\text { from homeland }\end{array}$ & $\mathrm{r}$ & $0.451^{* *}$ & $0.469 * *$ & $0.379 * *$ & $0.491 * *$ & 0.080 & $0.323 * *$ & -0.065 & 0.061 & -0.150 & -0.040 & 0.076 & $0.244 *$ \\
\hline $\begin{array}{c}\text { Wanted to return to } \\
\text { homeland }\end{array}$ & $r$ & $0.407 * *$ & $0.402 * *$ & $0.355^{* *}$ & $0.440 * *$ & -0.008 & $0.243^{*}$ & -0.126 & -0.011 & -0.170 & -0.090 & -0.024 & 0.160 \\
\hline
\end{tabular}

**Correlation is statistically significant on the level of 0.01

*Correlation is statistically significant on the level of 0.05

$\dagger$ Syndromes/profiles of subjects according the Achenbach check list of children behavior - Teacher's report form

tbowel movements out of toilet, brags, cruel to animals, doesn't eat well, bites nails, overeating, overweight, other physical problems, shows off, sleeps

more, talks too much, thumb sucking, wets self (day), wets the bed, whining, wishes to be opposite sex, and other problems.

Table 7. Spearman's " $\rho$ " coefficient of correlation between acculturation and repatriation problems among the returnee adolescents in postwar Bosnia and Herzegovina ( $\mathrm{n}=100$ ).

\begin{tabular}{|c|c|c|c|c|c|c|c|c|c|c|c|}
\hline $\begin{array}{l}\text { Acculturation } \\
\text { problems } \rightarrow \\
\text { Repatriation } \\
\text { problems } \quad \downarrow\end{array}$ & & $\begin{array}{c}\text { Sad after } \\
\text { coming to land } \\
\text { of exile }\end{array}$ & $\begin{array}{c}\text { Thought about } \\
\text { homeland } \\
\text { before coming } \\
\text { to land o exile }\end{array}$ & $\begin{array}{l}\text { Had trouble } \\
\text { sleeping }\end{array}$ & $\begin{array}{l}\text { Had troubles } \\
\text { with taking } \\
\text { food }\end{array}$ & Diet changed & $\begin{array}{l}\text { Couldn't play } \\
\text { outside }\end{array}$ & $\begin{array}{l}\text { Missed old } \\
\text { friends }\end{array}$ & $\begin{array}{l}\text { Thought about } \\
\text { cousins }\end{array}$ & $\begin{array}{l}\text { Listened to } \\
\text { news from } \\
\text { homeland }\end{array}$ & $\begin{array}{c}\text { Wanted to } \\
\text { come back to } \\
\text { homeland }\end{array}$ \\
\hline $\begin{array}{l}\text { Met with old } \\
\text { friends }\end{array}$ & $\rho$ & 0.103 & $0.348 * *$ & 0.009 & -0.181 & 0.044 & $0.473 * *$ & $0.263 * *$ & $0.391 * *$ & 0.163 & $0.260 * *$ \\
\hline $\begin{array}{l}\text { Going to school } \\
\text { with own } \\
\text { generation }\end{array}$ & $\rho$ & -0.120 & $-0.421 * *$ & 0.006 & 0.040 & 0.158 & -0.189 & 0.017 & $-0.272 * *$ & 0.072 & -0.134 \\
\hline $\begin{array}{c}\text { Has troubles } \\
\text { with studying at } \\
\text { school }\end{array}$ & $\rho$ & $0.239^{*}$ & 0.186 & 0.058 & -0.169 & $0.288 * *$ & $0.445 * *$ & $0.429 * *$ & $0.221 *$ & 0.181 & $0.394 * *$ \\
\hline $\begin{array}{l}\text { Sad after } \\
\text { returned }\end{array}$ & $\rho$ & -0.179 & 0.015 & -0.079 & -0.181 & -0.159 & -0.152 & $-0.355^{* *}$ & $-0.373 * *$ & -0.119 & -0.180 \\
\hline $\begin{array}{l}\text { Can't concentrate } \\
\text { at lessons in class }\end{array}$ & $\rho$ & 0.018 & 0.115 & 0.029 & -0.026 & 0.196 & $0.274 * *$ & 0.146 & -0.142 & -0.023 & 0.076 \\
\hline $\begin{array}{l}\text { Mostlywatching } \\
\text { satelliteTVon } \\
\text { thelanguage of } \\
\text { the countryin } \\
\text { whichhe } \\
\text { livedduring } \\
\text { theexile }\end{array}$ & $\rho$ & $-0.279 * *$ & $-0.289 * *$ & $-0.344 * *$ & $-0.383^{* *}$ & $-0.223^{*}$ & 0.048 & $-0.357 * *$ & $-0.252^{*}$ & $-0.360 * *$ & $-0.346^{* *}$ \\
\hline $\begin{array}{l}\text { Has trouble } \\
\text { sleeping }\end{array}$ & $\rho$ & -0.104 & $-0.228^{*}$ & -0.055 & -0.040 & $-0.203^{*}$ & $-0.414 * *$ & $-0.200^{*}$ & $-0.518^{* *}$ & -0.161 & -0.134 \\
\hline
\end{tabular}

**Correlation is statistically significant on the level of 0.01

*Correlation is statistically significant on the level of 0.05 .

Meeting with former comrades negatively associated with attention problems, rule violations, aggression and externalizing problems. Lack of going to school with own generation positively associated with breaking rules, aggressiveness and externalizing problems. Difficulties with learning of school materials negatively associated with rule violations and externalizing problems. Problems with communicating to relatives, friends and neighbors, directly correlated with anxious-depressive problems. Sadness after returning positively associated with social problems, attention problems, rule violations, aggressiveness, externalizing problems and other problems, while it inversely correlated with thought problems. Lack of concentration in the classroom directly correlated with the aggressiveness and externalizing problems. Watching satellite TV in the language of the country of exile is inversely correlated with anxiety-depressive behavior, withdrawal-depressive problems, and problems of internalization, and directly correlated with aggressiveness (Table 8). 
Hasanović M (2017) The acculturation and repatriation problems and school behavioral problems reported from teachers among repatriated refugee adolescents in Bosnia-Herzegovina

Table 8. Pearson correlation of behavioral problems (Achenbach) and acculturation problems between Youngerh $(\mathrm{n}=50)$ and Olderh $(\mathrm{n}=50)$ of returnees in Bosnia and Herzegovina

\begin{tabular}{|c|c|c|c|c|c|c|c|c|c|c|c|c|c|}
\hline $\begin{array}{c}\text { Behavioral problems } \\
\text { (Achenbach) } \dagger \rightarrow \\
\text { Repatriation problems } \\
\downarrow\end{array}$ & & $\begin{array}{l}\text { Anxious- } \\
\text { depressive }\end{array}$ & $\begin{array}{l}\text { Withdrawal- } \\
\text { depressive }\end{array}$ & $\begin{array}{c}\text { Somatic } \\
\text { difficulties }\end{array}$ & $\begin{array}{c}\text { Internalizing } \\
\text { problems }\end{array}$ & $\begin{array}{c}\text { Social } \\
\text { problems }\end{array}$ & $\begin{array}{l}\text { Thought } \\
\text { problems }\end{array}$ & $\begin{array}{l}\text { Attention } \\
\text { problems }\end{array}$ & $\begin{array}{c}\text { Breaking of } \\
\text { rules }\end{array}$ & Aggressiveness & $\begin{array}{c}\text { Externalizing } \\
\text { problems }\end{array}$ & $\begin{array}{c}\text { Other } \\
\text { problems } \ddagger\end{array}$ & $\begin{array}{c}\text { Total } \\
\text { problems }\end{array}$ \\
\hline Met with old friends & $\mathrm{r}$ & 0.133 & 0.037 & 0.012 & 0.072 & -0.139 & 0.122 & $-0.207^{*}$ & $-0.278 * *$ & $-0.265 * *$ & $-0.285 * *$ & -0.135 & -0.126 \\
\hline $\begin{array}{l}\text { Doesn't go to school } \\
\text { with own generation }\end{array}$ & $\mathrm{r}$ & -0.094 & -0.027 & -0.016 & -0.054 & 0.113 & -0.022 & 0.154 & $0.279 * *$ & $0.231^{*}$ & $0.269 * *$ & 0.067 & 0.115 \\
\hline $\begin{array}{l}\text { Has difficulties with } \\
\text { school material }\end{array}$ & $\mathrm{r}$ & 0.003 & -0.151 & 0.093 & -0.022 & -0.069 & 0.117 & -0.092 & $-0.265 * *$ & -0.124 & $-0.208^{*}$ & $-0.236^{*}$ & -0.145 \\
\hline $\begin{array}{l}\text { Has communication } \\
\text { problems with friends, } \\
\text { neighbors and family }\end{array}$ & $\mathrm{r}$ & $0.203^{*}$ & -0.033 & -0.031 & 0.060 & 0.025 & 0.110 & 0.014 & -0.002 & 0.005 & 0.001 & -0.101 & 0.016 \\
\hline Sad after return & $\mathrm{r}$ & -0.061 & -0.088 & -0.080 & -0.086 & $0.307 * *$ & $-0.257 * *$ & $0.290 * *$ & $0.203^{*}$ & $0.343^{* *}$ & $0.282^{* *}$ & $0.235^{*}$ & 0.155 \\
\hline $\begin{array}{l}\text { Can't concentrate in } \\
\text { class }\end{array}$ & $\mathrm{r}$ & -0.082 & 0.000 & 0.087 & -0.003 & 0.051 & 0.068 & 0.131 & 0.185 & $0.202 *$ & $0.202 *$ & -0.004 & 0.094 \\
\hline Watches satellite TV & $\mathrm{r}$ & $-0.446^{* *}$ & $-0.534 * *$ & -0.169 & $-0.439 * *$ & 0.034 & -0.129 & 0.170 & -0.083 & $0.202 *$ & 0.053 & 0.040 & -0.157 \\
\hline
\end{tabular}

***orrelation is statistically significant on the level of 0.01

*Correlation is statistically significant on the level of 0.05

$\dagger$ Syndromes/profiles of subjects according the Achenbach check list of children behavior - Teacher's report form

t bowel movements out of toilet, brags, cruel to animals, doesn't eat well, bites nails, overeating, overweight, other physical

problems, shows off, sleeps more, talks too much, thumb sucking, wets self (day), wets the bed, whining, wishes to be opposite

sex, and other problems.

\section{Discussion}

Our study has shown that adolescents in both groups of refugees have been exposed to severe war trauma. All returnees have survived the war in Bosnia that was characterized by the massive displacement, disruption, loss of life, relatives and property, separations from family, bereavement, close contact with war and combat, and extreme deprivation [16]. The scale and severity of these traumatic experiences appear to be greater than those that were reported using a similar survey instrument for war-affected children in Greater Beirut and Kuwait, during the Iraqi invasion and occupation $[6,11,19]$.

There were worse outcomes that were observed for refugees living in institutional accommodations, experiencing restricted economic opportunity, repatriated to a country that they had previously fled [20]. We found that $14.0 \%$ of participants in this study lost father during the war, what is less than we found in the previous research among adolescents from Srebrenica, Zvornik and Bijeljina [10,21,22]. It is less than $28 \%$ of 95 Bosnian refugee children what found Papageorgiou et al. in their research [23]. In this research we found that $49 \%$ of adolescents lost some family member(s) and it is significantly more than in the previous studies [10,21,22]. Geltman et al. [24] found $71 \%$ of 31 Bosnian refugee children that have experienced the death of a close friend(s) or relative(s); Husain et al. [25] reported that $66 \%$ of the 521 Sarajevo children lost a family member; in our previous study (2) we found $61.9 \%$ of 239 adolescents that lose family members.

Older adolescents in this study experienced separation from family and friends significantly more than younger ones ( $52 \%$ vs. $18 \%$ ), it was more than in similar studies $[24,26]$.

Regarding acculturation problems, most adolescents reported about their thinking about their relatives and about places of their origin. Older students reported significantly more often these two acculturation problems than younger, while younger respondents significantly more frequently expressed that they couldn't play games outside.

According difficulties experienced during repatriation, the most frequent repatriation problems that adolescents reported after returning to homeland were: "Met new friends upon return", "School system was different than in foreign country", "Mostly watched satellite
TV programs on foreign country language". About half of them didn't met old friend(s) after retuned to homeland. About one third of them had difficulties in mastering school material in mother language school, didn't attend school with own generation, and had sleeping problems. About one fifth reported lack of concentration to school lessons. About $4-5 \%$ of students reported difficulties in communication with cousins and teachers after returned, respectively. Only two younger students reported Alimentary problems. In terms of frequency of repatriation problems among young and elderly subjects were no statistically significant differences. It is similar like in previous studies $[2,10]$.

The most frequent school behavior problem that students showed in clinical and border-line manifestation reported from their teachers were "other problems", that considers: bowel movements out of toilet, brags, cruel to animals, doesn't eat well, bites nails, overeating, overweight, other physical problems, shows off, sleeps more, talks too much, thumb sucking, wets self (day), wets the bed, whining, wishes to be of the opposite sex, and other problems. About one tenth of students had anxious-depressive and withdrawal-depressive problems and somatic difficulties. Only few students had social and thought problems. In terms of the frequency of behavioral problems in school that observed teachers of examined students, there were no statistically significant differences in the clinical and/or border-line manifestation of listed problem, except for border-line forms of internalizing problems, where younger students reported a significantly higher frequency than high school students.

Older adolescents showed significantly higher scores on the T-scale for: thought problems, breaking rules, aggressive behavior, externalizing problems, other problems and total problems.

Acculturation problems were highly correlated with occurrence of school emotional/behavioral problems.

Students who were sad in the exile, who had different diet and who had sleeping difficulties, who listened to news from homeland and desired to return back to homeland had more anxious-depressive, withdrawal-depressive problems, with somatic difficulties, internalizing problems and thought problems. Those who were thinking about own home after arrived to the place of exile had more anxious-depressive and withdrawal-depressive problems, somatic difficulties, and 
internalizing problems; but they had less attention problems, breaking of rules, aggressiveness and total problems.

Students with alimentary problems in exile had more anxiousdepressive and withdrawal-depressive problems as well as internalizing problems and problems with breaking rules. Adolescents who couldn't play games outside had more thought problems but they had less: attention problems, breaking of rules, aggressiveness, externalizing, other problems and total problems. Students, who successfully accepted new environment in exile, had less: somatic difficulties, thought problems, other problems and total problems. Those who reposted the loss of old friends during exile had less social problems, attention problems, aggressiveness, externalization and other problems. Students who thought about cousins in exile had less social problems, attention problems, breaking the rules, aggressiveness, externalizing, other and total problems.

Students who preferred watching satellite TV program mostly on foreign language of the country of exile, who were sad after returning and who had problems with sleeping after returning had significantly less acculturation problems during the stay in exile. On the other side the students who had difficulties with studying of school material had most of acculturation problems during exile.

Students who met former comrades had less attention problems, breaking of rules, aggressiveness and less externalizing problems. Those who experienced lack of attending to school with own generation reported more breaking rules, aggressiveness and externalizing problems. Students with difficulties with learning of school materials reported less breaking rules and less externalizing problems. Adolescents who had problems in communication with relatives, friends and neighbors had more anxious-depressive problems. Those who were sad after returning to homeland had more social problems, attention problems, breaking rules, aggressiveness, externalizing problems and other problems, while they had less thought problems. Students who suffered from bad concentration in the classroom had more aggressiveness and more externalizing problems. Watching satellite TV in the language of the country of exile was protective behavior against anxiety-depressive behavior, withdrawal-depressive problems, and problems of internalization, but increased aggressiveness of students.

The acculturation process after returning to ones' home country is very complex, long-lasting process, regarding all emotional, sociopolitical and financial obstacles they have to face and to go over it with minimal harm $[2,10,16]$.

The findings of this survey of Bosnia-Herzegovina refugee adolescents living in post war conditions after surviving fighting, expelling homes, displacement, exile, acculturation, repatriation, loss of fathers, close family members' loss, loss of property, lack of safety and normal conditions for life today and in the future suggest that the impact the war left was both severe and widespread. The young Bosnians examined are a multi-traumatized group [2,6,10,19]. Adolescents who had more war experiences were associated with greater symptomatology. Our findings show that young people who were forced to leave their property, original places, and country during wartime may have more serious, longer-term psychological problems $[10,14]$. A variety of serious psychological manifestations, including anxiety, withdrawal, sadness, introversion, thought, and attention problems were revealed in the adolescents that were examined. The process that was used to identify and measure symptoms, however, should be looked upon with a certain dose of caution. Thorough psychiatric evaluations that determine diagnoses cannot be replaced by survey techniques $[6,10]$.

Children who fled their homes together, or without complete families, were likely to have had particularly harsh war experiences. The findings from this study are likely to reflect the experience of a large portion of Bosnian younger population, as suggested by the wide distribution of the fighting and the large numbers of families displaced by the war. This might be considered as a general characteristic of a society at war $[10,27]$.

Our findings confirmed prior researches that have shown, that young refugees may be especially traumatized [2,6,10,28-30]. The findings of this study may be viewed differently from the studies performed outside of areas of conflict, as they document and extend our understanding of the relatively acute effects of war on children and adolescents in the midst of post war conflict, and immediately post conflict, where life conditions were abnormal and conditions for real and completed repatriation were not achieved $[5,6,10]$.

In this study we cannot say if the reported school behavioral problems were results of war traumatization or acculturation in exile or acclimatization during repatriation. This investigated population could not be followed up in future because of coming different migrations and new resettlements in near perspectives toward their original settlements which are unpredictable. Practically it is impossible collect data again from the same participants to record additional psychosocial changes they will pass through their developmental periods $[2,10]$.

This experience needs to address the effects of war on children's (13 ) and adolescents' mental health, while underscoring the vulnerability of civilians in areas of conflict $[5,10,21,22]$. The experiences of Bosnian repatriated refugee adolescents that were exposed to war, and their psychological states, are important for the educational and medical community to document and understand adolescents' postwar problems, such information is useful in reminding those who are planning, and are actively engaging in relief operations of the full range of needs that adolescents, living in post-war areas and areas of political and economic conflicts, may have $[2,6,28]$. There is a strong need to evaluate various methods of delivering help and developing new ways of reaching needy children and adolescents in a way that is non-stigmatizing [10,29].

Understanding these processes, while understanding the views of repatriated refugees or those refugees who seek asylum in host country or plan repatriation to home country, should guide policies of postconflict management while planning for the long-term, and being more focused on the human factors rather than only rules and properties $[10,30]$. The findings, with respect to repatriation, going back to own property and reconstruction, point to major challenges. These findings highlight the importance of family reunification and the facilitating of decision-making by the people that were affected themselves [10]. In the postwar Bosnia-Herzegovina people who survived war are faced every day with problems that are associated with over-dependence on external assistance. This study, therefore, could emphasize the need for people to be given the means of using their skills and knowledge to control their daily lives $[10,16,31,32]$.

\section{Conclusions}

All respondents in the sample have a significant number of traumatic experiences. Losing his/her father and family member(s) are very significant catastrophic events, which determine the specific implications for the normal development of young people after this loss. 
Younger respondents show low adaptability, and tendency to internalization. Older respondents showed intense externalizing and other problems

The most prominent acculturative problems of returnees during the stay abroad are: thinking about relatives, thinking about his native village on arrival at the place of exile, absence of friends, the desire to return home, listening to the news from home, an intense feeling of sadness on arrival in the country exile.

Highly present repatriation problems that respondents encounter returning to their homeland are: school system is different compared to the land of their captivity; respondents at home mostly watch satellite $\mathrm{TV}$; worse economic situation than before the exile; extreme sadness, missed a meeting with former friends on arrival home.

Teachers have noticed a number of behavioral disorders that returnees showed higher mal-adaptation during repatriation.

Returnees who had more acculturative problems abroad, showed more functional and relational problems at home after returning, while showing less psycho-emotional problems.

Schools, and other various institutions that are dealing with education and upbringing of young people should start developing programs that will direct these issues.

\section{Acknowledgment}

Our special acknowledgments are addressed to adolescents themselves, their parents, their teachers and many other real friends, owing to their contributions to this research. Thanks to our wives and our children who were supportive while this paper was being prepared.

\section{Conflict of interests}

Author declares that they have no conflict of interests. This study was not sponsored by any external organization.

\section{Contributions}

M.H.: design of study, collecting of data, input of data in statistical package, statistical computing and analysis of data, writing of manuscript, intellectual contribution to manuscript.

I.P.: design of study, analysis of data, writing of manuscript, intellectual contribution to manuscript.

S.P.: design of study, statistical computing and analysis of data, writing of manuscript, intellectual contribution to manuscript.

\section{References}

1. Agius M, Glaurdic J. (2012) Remembering wars past. Paediatrics Today. 8: 1-4.

2. Hasanovic M, Sinanovi c O, Pavlovic S (2005) Acculturation and psychological problems of adolescents from Bosnia and Herzegovina during exile and repatriation. Croat Med J 46: 105-115. [Crossref]

3. Agius M, Butler S, Hasanovic M. (2012) Baseline self- reported functional health and vulnerability to posttraumatic stress disorder after combat deployment: prospective US military cohort study. Re: Posttraumatic Stress Disorder in Bosnia Herzegovina. BMJ, 338: b1273. [Crossref]

4. Ajdukovic D. (1994) Programs of psychosocial assistance. In: Psychosocial needs of refugees and assistance programs, internal material for a seminar in Sarajevo, 18-21 July.

5. Hasanovic M. (2011) Psychological consequences of war-traumatized children and adolescents in Bosnia and Herzegovina. Acta Medica Academica. 40: 45-66.

6. Goldstein RD, Wampler NS, Wise PH (1997) War experiences and distress symptoms of Bosnian children. Pediatrics 100: 873-878. [Crossref]
7. Brennen T, Hasanovic M, Zotovic M, Blix I, Skar AM, Prelic NK, et al. (2010) Trauma exposure in childhood impairs the ability to recall specific autobiographical memories in late adolescence. J Trauma Stress. 23: 240-247.

8. Kravic N, Pajevic I, Hasanovic M (2013) Surviving genocide in Srebrenica during the early childhood and adolescent personality. Croat Med J 54: 55-64. [Crossref]

9. Bull D. (2004) Operation joint forge veterans - Balkan tour broadens scope. Vet. Center Voice. 25: 12-16.

10. Johnson TM. (2011) Acculturation: Implications for Individuals, Families and Societies. New York: Nova Publishers. (1st Quarter). 197-233.

11. Kett ME. (2005) Internally displaced peoples in Bosnia-Herzegovina: impacts of longterm displacement on health and well-being. Med Conf Surviv. 21: 199-215.

12. Miller KE, Weine SM, Ramic A, Brkic N, Bjedic ZD, et al. (2002) The relative contribution of war experiences and exile-related stressors to levels of psychological distress among Bosnian refugees. J Trauma Stress. 15: 377-87.

13. Nader K. (1997) Assessing traumatic experiences in children: the need for assessment In: Wilson J, Keane T, editors. Assessing psychological trauma and PTSD. The Guilford Press. 292-293.

14. Hunt N, Gakenyi M (2005) Comparing refugees and nonrefugees: the Bosnian experience. J Anxiety Disord 19: 717-723. [Crossref]

15. Nader KO. (1997) Childhood traumatic loss: the interaction of trauma and greef In: Figley CR, Bride BE, Mazza N, editors. Death and trauma: the traumatology of grieving. Washington DC: Taylor and Francis. 17-42.

16. Carballo M, Smajkic A, Zeric D, Dzidowska M, Gebre-Medhin J, et al. (2004) Menta health and coping in a war situation: the case of Bosnia and Herzegovina. $J$ Biosoc $S c i$ 36: 463-477. [Crossref]

17. American Psychiatric Association. (1993) Diagnostic and statistical manual of mental disorders (4th edition). Washington, DC: American Psychiatric Association.

18. Achenbach TM, McConaughy SH. (1997) Empirically based assessment of child and adolescents psychopathology: Practical applications. Thousand Oaks. Sage.

19. Elklit A, Nørregaard J, Tibor B (1998) [Occurrence and type of traumatic experience among young Bosnian refugees in Denmark]. Ugeskr Laeger 160: 4310-4314. [Crossref]

20. Porter M, Haslam N. (2005) Predisplacement and postdisplacement factors associated with mental health of refugees and internally displaced persons: a meta-analysis. JAMA 294: 602-612.

21. Hasanovic M. (2012) Posttraumatic Stress Disorder of Bosnian internally displaced and refugee adolescents from three different regions after the war 1992-1995 in BosniaHerzegovina. Paediatrics Today 8: 22-31.

22. Hasanovic M. (2012) Neuroticism and Posttraumatic Stress Disorder in Bosnian internally displaced and refugee adolescents from three different regions after the war 1992-1995 in Bosnia-Herzegovina. Paediatrics Today 8: 100-113.

23. Papageorgiou V, Frangou-Garunovic A, Iordanidou R, Yule W, Smith P, et al. (2000) War trauma and psychopathology in Bosnian refugee children. Eur Child Adolesc Psychiatry 9: 84-90. [Crossref]

24. Geltman PL, Augustyn M, Barnett ED, Klass PE, Groves BM. (2000) War trauma experience and behavioral screening of Bosnian refugee children resettled in Massachusetts. J Dev Behav Pediatr 21: 255-261.

25. Husain SA, Nair J, Holcomb W, Reid JC, Vargas V, et al. (1998) Stress reactions of children and adolescents in war and siege conditions. Am J Psychiatry 155: 1718-1719. [Crossref]

26. Ajdukovi c M (1998) Displaced adolescents in Croatia: sources of stress and posttraumatic stress reaction. Adolescence 33: 209-217. [Crossref]

27. Franciskovic T, Moro L, Toric I, Urlic I, Roncevi c-Grzeta I, et al. (2000) The impact of traumatic experience on attitude towards future in refugee adolescents. Coll Antropol 24: 579-584. [Crossref]

28. Baràth A (2002) Psychological status of Sarajevo children after war: 1999-2000 survey Croat Med J 43: 213-220. [Crossref]

29. Yule W (2000) From pogroms to "ethnic cleansing": meeting the needs of war affected children. J Child Psychol Psychiatry 41: 695-702. [Crossref]

30. Van der Kolk BA, McFarlane AC. (1996) "The black hole of trauma" in van der Kolk BA, McFarlane AC and Weisaeth L. (Eds.) Traumatic stress. The effects of overwhelming experience on mind, body and society. Guilford Press, NY. 
Hasanović M (2017) The acculturation and repatriation problems and school behavioral problems reported from teachers among repatriated refugee adolescents in Bosnia-Herzegovina

31. Pajevic I, Hasanovic M, Kopric A (2010) Psychiatry in a battle zone. Bioethics 24: 304-307. [Crossref]
32. Hasanovic M, Herenda S. (2008) Post traumatic stress disorder, depression and anxiety among family medicine residents after 1992-95 war in Bosnia and Herzegovina. Psychiatr Danub. 20: 277-285.

Copyright: (C2017 Hasanović M. This is an open-access article distributed under the terms of the Creative Commons Attribution License, which permits unrestricted use, distribution, and reproduction in any medium, provided the original author and source are credited. 